\title{
Effects of ultraviolet-B radiation on two arctic microbial food webs
}

\author{
Stephen Wickham ${ }^{1,2, *}$, Marina Carstens ${ }^{3}$ \\ ${ }^{1}$ Max Planck Institute for Limnology, Postfach 165, D-24302 Plön, Germany \\ ${ }^{2}$ Zoological Institute, University of Cologne, Weyertal 119, D-50923 Köln, Germany \\ ${ }^{3}$ Institute for Polar Ecology, Wischhofstr. 1-3, Geb. 12, D-24148 Kiel, Germany
}

\begin{abstract}
The impact of UVB radiation on arctic planktonic microbial communities was examined in 2 shipboard experiments conducted on the northeast coast of Greenland, using water from a sea-ice meltwater pond and a land pond. The experiments were designed as a preliminary investigation of the interaction of UVB and grazer effects on microbial communities, in order to evaluate the net effect of UVB on intact communities. We used Mylar bags to remove the natural levels of UVB, and a variation of the Landry-Hassett type dilution design to manipulate grazer abundance. The experiments allowed UVB effects to be scaled relative to grazing intensity and to growth in the absence of grazing. UVB effects on ciliates and rotifers were highly species-specific and ranged from no growth rate enhancement with the removal of UVB, to strong enhancement, and even to higher numbers in the presence, rather than absence, of UVB. Removal of UVB had little or no effect on heterotrophic flagellates. Nanoand picoplanktonic algae were suppressed by UVB in only 1 experiment, and bacteria showed no enhancement in the absence of UVB in either experiment. When UVB effects occurred in nano- or picoautotrophs or HNF, they were substantially smaller than the mortality produced through grazing. It would appear that at current UVB levels, community-level deleterious effects of UVB on arctic microbial food webs can be difficult to discern, due to the species-specificity of the effects.
\end{abstract}

KEY WORDS: Ultraviolet-B radiation $\cdot$ Microbial $\cdot$ Ciliate $\cdot$ Arctic $\cdot$ Freshwater

\section{INTRODUCTION}

The depletion of stratospheric ozone, and the subsequent increase in surface-level ultraviolet- $B$ radiation (UVB, 280 to $320 \mathrm{~nm}$ ), has the potential to affect many aspects of aquatic ecosystems. There has been a considerable amount of work showing deleterious effects of UVB particularly on algae and metazoan zooplankton, but negative effects on heterotrophic nanoflagellates (HNF) and bacteria have also been observed (Siebeck 1978, Holm-Hansen et al. 1989, Cullen et al. 1992, Herndl et al. 1993, Williamson et al. 1994, Müller-Niklas et al. 1995, Jeffrey et al. 1996, Sommaruga et al. 1996). Species-specific differences in susceptibility to UVB damage have been seen for both

\footnotetext{
- Present address: Zoological Institute, University of Cologne, Weyertal 119, D-50923 Köln, Germany.

E-mail:swickham@biolan.uni-koeln.de
}

algae and metazoan zooplankton, and it has been proposed that UVB may be able to affect algal community composition (Williamson et al. 1994, Zellmer 1995, Davidson et al. 1996). Habitat and prior exposure to UVB may also play a role in determining the amount of UVB damage. Algae from tropical oceans, which receive high UVB loads, have been shown to be less vulnerable than algae from Antarctic waters (Helbling et al. 1992). In addition, removal of in situ UVB in a eutrophic lake with low UVB penetration had less of an effect on the resident zooplankton than in an oligotrophic lake with deeper UVB penetration (Williamson et al. 1994).

Despite the work on the effect of UVB on individual aspects of aquatic ecosystems, there has been relatively little work on entire ecosystems. In one study that did examine several trophic levels simultaneously, periphyton biomass increased in the presence of UVB, due to the suppression of a chironomid grazer (Both- 
well et al. 1994). However, in a second study of periphyton response to UVB presence/absence, where chironomids were not abundant, absence of UVB produced an overall increase in periphyton chiorophyll a (Vinebrooke \& Leavitt 1996). In addition, lower bacterivory has been observed in HNF exposed to UVB (Sommaruga et al. 1996). Clearly, the net effect of UVB on one trophic level is dependent not only on the direct deleterious effects on that trophic level, but also on the effects on higher and lower trophic levels.

In order to examine some of the direct and indirect effects of UVB radiation on microbial food webs, we conducted experiments with entire microbial communities where we manipulated both UVB and grazer levels. The experiments were designed as preliminary investigations to determine whether UVB effects are likely to be seen in complete microplankton communities, as opposed to species-specific or trophic-levelspecific responses, and to scale UVB effects to grazer impact.

\section{MATERIALS AND METHODS}

The study area was the east coast of Greenland, between $75^{\circ}$ and $71^{\circ} \mathrm{N}$. Polar regions are expected to receive a proportionately greater increase in UVB radiation due to ozone depletion (Madronich 1992), and are therefore of particular interest. The experiments were carried out as part of the Polarstern ARKTIS-X/2 cruise, during the period 21 August to 25 September 1994. Two shipboard experiments were conducted, using water and plankton communities from a sea-ice meltwater pond and a shallow, turbid land pond. The sea-ice meltwater pond was not open to the sea beneath the ice, and was freshwater, with $0 \%$ salinity. The pond was approximately 17 by $11 \mathrm{~m}$ in size, with a maximum depth of $30 \mathrm{~cm}$, and was located in drift ice at $74^{\circ} 58^{\prime} \mathrm{N}, 10^{\circ} 19^{\prime} \mathrm{W}$. The second dilution experiment utilized water from a large pond on Shannon Island, $75^{\circ} 03^{\prime} \mathrm{N}, 18^{\circ} 46^{\prime} \mathrm{W}$, unofficially named 'Potsdam Lake' during the cruise. Potsdam Lake is approximately $1.3 \mathrm{~km}$ long, $200 \mathrm{~m}$ wide, with a maximum depth of $70 \mathrm{~cm}$, and is turbid from resuspended sediments (Melles et al. 1995)

As experimental containers, 3.5 I polyethylene

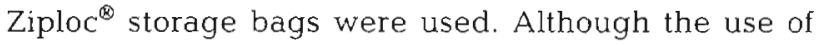
polyethylene containers in UV work has been criticized (Holm-Hansen \& Helbling 1993), this criticism is itself controversial (Prézelin \& Smith 1993), and polyethylene has been routinely used for UV studies (Williamson et al. 1994, Davidson et al. 1996, Lindell \& Edling 1996). Removal of UVB in half the bags was accomplished by placing the polyethylene bag within a second, Mylar bag with a $70 \mu \mathrm{m}$ wall thickness. The spectral absorbance characteristics of both the polyethylene and the combination of Mylar and polyethylene bags were checked with a Uvikon 930 spectrophotometer. The polyethylene bags are transparent in both the PAR (photosynthetically active radiation, 400 to $700 \mathrm{~nm}$ ) and the UVB range, absorbing between 5 and $10 \%$ of incident radiation. Mylar gives a cut off beginning at approximately $325 \mathrm{~nm}$, absorbing between 90 and $95 \%$ of radiation in the UVB range (Fig. 1). Above $400 \mathrm{~nm}$, the absorbance by the Mylar/ polyethylene combination alone was only marginally higher than polyethylene alone.

Initial and final samples were taken for bacteria, flagellates, ciliates and chlorophyll $a$, DOC and, in the Potsdam Lake dilution experiment, for metazoan zooplankton. Whole-water, $250 \mathrm{ml}$ samples were fixed in $2 \%$ glutaraldehyde for bacteria and flagellates, and stored at $4^{\circ} \mathrm{C}$ until further processing. Bacteria and flagellates were counted by filtering $100 \mathrm{ml}$ samples down to $10 \mathrm{ml}$ (sea-ice meltwater pond), or directly using $10 \mathrm{ml}$ samples (Potsdam Lake experiment), staining with DAPI (1 $\mathrm{gg} \mathrm{m}^{-1}$ final concentration), and filtering onto $0.2 \mu \mathrm{m}$ pore size polycarbonate filters. Bacteria and flagellate counts were done within a week of the completion of the experiment. Ciliates were preserved in Bouin's fixative, and $100 \mathrm{ml}$ sub-samples were settled (50 $\mathrm{ml}$ for the Potsdam Lake experiments) and counted in their entirety. Ciliates were identified to genus or species using the Skibbe (1994) modification of the Montagnes \& Lynn (1987) Quantitative Protargol Staining (QPS) methodology. Chlorophyll a samples (2.5 l for the meltwater pond experiment, $400 \mathrm{ml}$ for the Potsdam Lake experiment) were filtered onto GF/F filters and then frozen. Chlorophyll a was later extracted with methanol and measured spectrophotometrically (Nusch \& Palme 1975). Metazoan zooplankton (metazooplankton) were sampled in the Potsdam Lake experiment, and were collected by filtering the remaining contents of the experimental bags through a $20 \mu \mathrm{m}$ mesh and preserving in formaldehyde ( $4 \%$ final concentration). Whole-water samples $(200 \mathrm{ml})$ were frozen for later nutrient analysis and for spectral absorbance analysis, performed on a dualbeam Uvikon 930 Kontron Instruments Spectrophotometer with $1 \mathrm{~cm}$ pathlength cuvettes (Fig. 1). Wholewater samples were also frozen for DOC analysis. DOC was analyzed using HTCC (High Temperature Catalytic Combustion).

The experiments were a modification of the Landry \& Hassett (1982) dilution design. This method uses varying dilutions of whole water with filtered water to alter the encounter rate of predators with their prey, and therefore alter the net growth rate of the prey. At higher dilutions, the encounter rate between predator and prey will be lower, decreasing the predation rate 

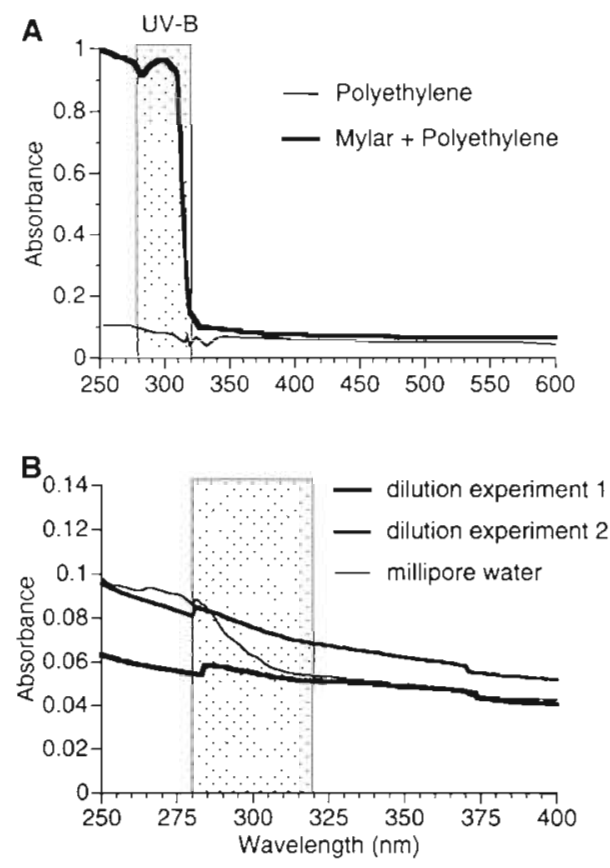

Fig. 1. Absorption profiles for plastics and water used in the experiments. (A) Absorbance of the polyethylene bag alone, or the polyethylene and Mylar bags together. The stippled region is the UVB range ( 280 to $320 \mathrm{~nm}$ ). (B) Absorption profiles of the water used in the dilution experiments (dilution experiment 1: sea-ice meltwater pond dilution experiment 2: Potsdam Lake), with an absorbance profile of millipore deionized water as reference

and increasing the net growth rate of the prey. When the net growth rates are regressed against the proportion of whole water, the intercept (at the theoretical $0 \%$ whole water, where predators would be totally absent) gives the growth rate of the prey in the absence of predation, while the slope of the regression gives the grazing rate of the predators. Whole water was diluted with $0.2 \mu \mathrm{m}$ filtered water from the same source. Dilutions of $100,80,65,50$, and $35 \%$ whole water were used in the experiments. The net growth rate $(g)$ of the phytoplankton, HNF and bacteria in each bag was calculated using the formula

$$
g=\frac{\ln \left(N_{\mathrm{E}} / N_{\mathrm{B}}\right)}{t}
$$

where $N_{E}$ and $N_{B}$ are the number of prey at the end and beginning of the experiment, respectively, and $t$ is the duration of the experiment. $N_{\mathrm{B}}$ was calculated from the cell densities in initial, undiluted samples, multiplied by the dilution fraction. The assumption that the actual prey growth rates are independent of the dilution fraction only holds if nutrients are not limiting in all treatments (Landry \& Hassett 1982). In order to meet that assumption, $0.82 \mathrm{mg} \mathrm{P}^{-1}$ phosphate, $9.2 \mathrm{mg}$ $\mathrm{N} \mathrm{l}^{-1}$ nitrate and $1 \mathrm{mg}$ glucose $\mathrm{l}^{-1}$ were added to all bags. The nutrient levels were chosen on the basis of previously recorded low nutrient levels for ice floe melt-water ponds (Carstens unpubl.) as being likely to be nonlimiting over the course of the experiments. DOC addition can change the optical properties of the water, but the DOC-light penetration model of Williamson et al. (1996) indicated that a $1 \mathrm{mg} \mathrm{DOC} \mathrm{m}^{-1}$ addition would reduce the UVB penetration at the bottom of the experimental bags $(15 \mathrm{~cm}$ ) from 89 to $63 \%$ of incipient UVB radiation in the first, and from 62 to $42 \%$ of incipient UVB in the second, dilution experiment. Reductions in DOC penetration would be even less nearer the tops of the bags.

The dilution design was run in parallel, in 3.51 polyethylene bags with or without Mylar bags, with replicate bags for each combination of dilution and UVB presence/absence (i.e. 5 dilution levels $\times 2$ replicates $\times$ 2 UVB levels [presence/absence] $=20$ bags per experiment; Table 1). The data were then analyzed in an ANCOVA design. ANCOVA tests whether the intercepts and the slopes, with and without UVB, are significantly different. If the intercepts are different, then there is a significant difference in the growth rate of the prey due to UVB, in the absence of predation. If the slopes of the regressions are significantly different, then the grazing rates are UVB-dependent, and the net effect of UVB on the prey is dependent on the predator concentration. Because all effects are measured in growth rate units, the size of the grazing and UVB effects can be expressed in relative terms, as a percentage of the growth rate in the absence of predation. The full ANCOVA model, with the interaction term,

Table 1. Location of sampling stations, starting dates, duration and initial conditions for the 2 experiments. Water temperature is the mean temperature (measured daily) over the course of the experiments. Chlorophyll $a$, nutrient levels, and the abundances of bacteria, HNF, ciliates and rotifers are the mean initial abundances

\begin{tabular}{|c|c|c|}
\hline & $\begin{array}{c}\text { Sea-ice melt- } \\
\text { water pond } \\
\text { (drift ice, } \\
74^{\circ} 58^{\prime} \mathrm{N} \\
10^{\circ} 19^{\prime} \mathrm{W} \text { ) }\end{array}$ & $\begin{array}{l}\text { Potsdam Lake } \\
\text { (Shannon } \\
\text { Island, } \\
75^{\circ} 03^{\prime} \mathrm{N} \\
18^{\circ} 46^{\prime} \mathrm{W} \text { ) }\end{array}$ \\
\hline Beginning date & 21 Aug 1994 & 30 Aug 1994 \\
\hline Duration (days) & 8 & 9 \\
\hline Water temperature $\left({ }^{\circ} \mathrm{C}\right)$ & 3.8 & 5.2 \\
\hline Chl $a\left(\mu \mathrm{g} \mathrm{chl} a \mathrm{l}^{-1}\right)$ & 0.08 & 1.2 \\
\hline Phosphate $\left(\mu \mathrm{g} \mathrm{Pl}^{-1}\right)$ & 3.3 & 5.3 \\
\hline Nitrate $\left(\mu \mathrm{g} \mathrm{N}^{-1}\right)$ & Not determined & 6.7 \\
\hline $\mathrm{DOC}\left(\mathrm{mg} \mathrm{Cl}^{-1}\right)$ & $<1$ & 1.5 \\
\hline Bacteria $\left(\times 10^{6}\right.$ cells $\left.\mathrm{ml}^{-1}\right)$ & 0.0314 & 2.09 \\
\hline $\mathrm{HNF}\left(\times 10^{3}\right.$ cells $\left.\mathrm{ml}^{-1}\right)$ & 0.378 & 2.88 \\
\hline Total ciliates (cells $\mathrm{ml}^{-1}$ ) & 2.14 & 3.90 \\
\hline Total rotifers (rotifers $\mathrm{ml}^{-1}$ ) & 0 & 31.4 \\
\hline
\end{tabular}


was first run. If the interaction was not significant, the analysis was then rerun, without the interaction term, in order to get a better estimate of the grazing and growth parameters (Sokal \& Rohlf 1995). A potential problem with this design is if, at the lowest dilutions (highest percentage whole water), the prey concentrations are above the incipient limiting levels of the predators (the prey level at which predator ingestion rate is maximal, and the grazing rate is no longer independent of the prey concentration). If the prey concentration is above this level, then predation rates will no longer be a linear function of the dilution factor (Gallegos 1989). In order to check for this, the data were first fit to a quadratic regression, with the intercept, dilution factor, and dilution factor squared as the terms in the regression. If the quadratic term of the regression was significantly different from zero, then the data were deemed nonlinear, and the $100 \%$ whole-water treatment was removed from the analysis. The quadratic regression was then run again, but there were no cases where the data were nonlinear after the $100 \%$ wholewater treatment was removed.

Because the microzooplankton predators (ciliates and rotifers) could be expected to grow over the course of the experiments, but at varying rates (lower growth rates at higher dilutions), an a priori assumption of a linear relationship between final predator abundance and dilution factor may not hold. As a result, predator final abundance data were analyzed in a 2-way (UVB by dilution factor) ANOVA, with the dilution factor considered as a discrete, rather than a continuous, factor. In cases where there were low abundances of the predators, the data were square root transformed to normalize the expected Poisson distributed data (Winer 1971). The data were back-transformed when presented in the figures.

The first (sea-ice meltwater pond) experiment was begun on 21 August 1994 and ended 8 d later. The second (Potsdam Lake) experiment was begun on 30 August 1994 and ended $9 \mathrm{~d}$ later. The protocol for the 2 dilution experiments was the same. Whole water samples were brought by helicopter in carboys from the ponds. We began to set up the experiments immediately after returning to the ship. and carboys were stored in a $4^{\circ} \mathrm{C}$ cold room until used. Water from the site was filtered through a $0.2 \mu \mathrm{m}$ pore-size cartridge (with a glass-fiber prefilter) to obtain water for the dilutions. Whole and filtered water was added to bags to obtain the appropriate dilutions, and nutrients were added. Treatment assignments were made in a random order. The bags were incubated at the surface of seawaterfilled $65 \mathrm{l}$ plastic containers. Seawater was flowed through the containers to reduce temperature variation. The water temperature in the containers was checked daily, and the mean temperature was $3.8^{\circ} \mathrm{C}$ in the meltwater pond experiment and $5.2^{\circ} \mathrm{C}$ in the Potsdam Lake experiment.

\section{RESULTS}

The first dilution experiment was conducted with water from a sea-ice meltwater pond. The pond had extremely low nutrient and DOC levels, beneath the detection limit, typical for this type of pond (Carstens unpubl., Table 1). When equations that relate UVB penetration to DOC content (Williamson et al. 1996) were applied, $1 \%$ UVB penetration depth was calculated to be well beneath the maximum depth of the pond, giving us a microbial community that had been exposed to high UVB loads. While initial bacteria and HNF levels were low, initial total ciliate abundance was relatively high (Table 1 ). The ciliate community was dominated by a Strombidium species, but there were 4 species found, including the predatory Lacrymaria papula. Low numbers (initial abundance 0.14 cells $\mathrm{ml}^{-1}$ ) of a heliozoan were also found.

In the absence of predation, the nanoautotroph community grew at a rate only marginally greater than zero (Fig. 2). The picoautotrophs, in contrast, grew quickly despite the low temperatures, with a maximal rate of $0.553 \mathrm{~d}^{-1}$ in the absence of predation (Fig. 2, Table 2). Both pico- and nanoautotrophs were grazed by the pro-
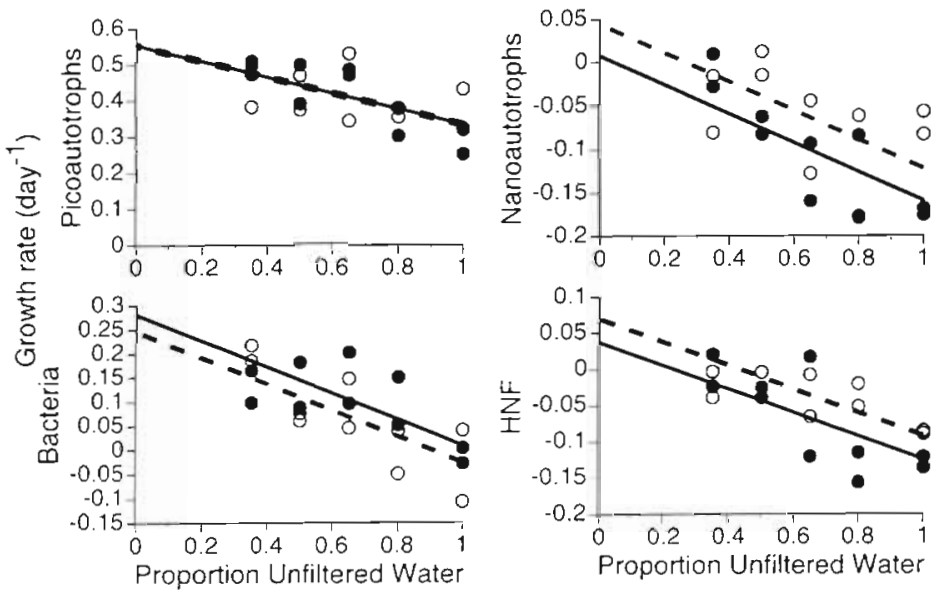

Fig. 2. Sea-ice meltwater pond dilution experiment. Regressions of proportion unfiltered water against nel growth rate (per day) for pico- and nanoautotrophs, bacteria, and HNF. (-O-) UVB absent treatments, $(\rightarrow-)$ UVB present treatments. The slopes of the lines are the grazing rates, the intercepts are the growth rates in the absence of grazing. The $\mathrm{R}^{2}$ values for the ANCOVA model fit and the estimates of the slope (grazing rate) and intercept (growth in the absence of grazing) are given in Table 2 
Table 2. P-values and parameter estimates for the dilution experiment ANCOVA. $\mathrm{R}^{2}$ is the proportion of total variance explained by the whole model. Intercept is the potential growth rate $\left(d^{-1}\right)$ of the response variables in the absence of both predation and UVB. The estimate of the UVB effect is the difference in mean growth rates in treatments with and without UVB. The dilution effect estimate is the slope of the regression, and is the reduction in growth rate due to the presence of grazers. The P-values for the UVB, dilution and interaction effects are the probabilities that the estimates of these effects are significantly different from zero. The UVB and dilution effect estimates are also expressed as a percentage of growth in the absence of both predation and UVB, when the effect is significantly different from zero. Because none of the interaction effects were significant, no estimates are given

\begin{tabular}{|c|c|c|c|c|c|c|c|c|c|}
\hline \multirow[t]{2}{*}{ Response variable } & \multirow[t]{2}{*}{$\mathrm{R}^{2}$} & \multirow[t]{2}{*}{ Intercept } & \multicolumn{3}{|c|}{ UVB effect } & \multicolumn{3}{|c|}{ Dilution effect } & \multirow{2}{*}{$\begin{array}{c}\text { Interaction } \\
\mathrm{P}\end{array}$} \\
\hline & & & $\mathrm{P}$ & $\begin{array}{l}\text { Esti- } \\
\text { mate }\end{array}$ & $\begin{array}{l}\text { As \% of } \\
\text { intercept }\end{array}$ & $\mathrm{P}$ & $\begin{array}{l}\text { Esti- } \\
\text { mate }\end{array}$ & $\begin{array}{l}\text { As } \% \text { of } \\
\text { intercept }\end{array}$ & \\
\hline \multicolumn{10}{|c|}{ Dilution experiment 1 (meltwater pond) } \\
\hline Picoautotrophs & 0.40 & 0.553 & 0.99 & -0.00007 & - & 0.0032 & -0.220 & 40 & 0.11 \\
\hline Nanoautotrophs & 0.47 & 0.045 & 0.104 & 0.0370 & - & 0.0027 & -0.167 & 371 & 0.14 \\
\hline Bacteria & 0.56 & 0.245 & 0.21 & -0.0354 & - & 0.0003 & -0.272 & 111 & 0.31 \\
\hline HNF & 0.58 & 0.069 & 0.063 & 0.0329 & 47 & 0.0003 & -0.162 & 233 & 0.12 \\
\hline \multicolumn{10}{|c|}{ Dilution experiment 2 (Potsdam Lake) } \\
\hline Picoautotrophs & 0.75 & 0.223 & 0.0013 & 0.0521 & 23 & 0.0005 & -0.175 & 78 & 0.20 \\
\hline Nanoautotrophs & 0.68 & 0.165 & 0.014 & 0.0316 & 19 & 0.0006 & -0.148 & 90 & 0.15 \\
\hline Bacteria & 0.81 & 0.288 & 0.51 & 0.0089 & - & $>0.0001$ & -0.291 & 101 & 0.36 \\
\hline HNF & 0.44 & 0.091 & 0.76 & 0.0106 & - & 0.0073 & -0.328 & 359 & 0.66 \\
\hline
\end{tabular}

tist community over the course of the experiment (Fig. 2). The grazing rate was the equivalent of only $40 \%$ of the estimated maximal picoautotroph growth rate, but $371 \%$ of the maximal nanoautotroph growth rate (Table 2). There was a small but nonsignificant reduction in nanoautotroph growth rate due to the presence of UVB, but picoautotroph growth was virtually identical in the presence or absence of UVB (Fig. 2, Table 2). The presence or absence of UVB did not have a significant effect on the interaction between growth and grazing ( $p>0.1)$, suggesting that there was not a general UVB effect on the grazer community that would change the grazing rate in the presence or absence of UV (Table 2). The final abundance of the most abundant grazer, Strombidium sp., was not affected by the presence or absence of UVB ( $p=0.47$, Fig. 3), nor were Euplotes $\mathrm{sp}$. or the heliozoan ( $\mathrm{p}>0.6$ ). The predatory ciliate Lacrymaria papula had higher rather than lower abundance in the presence of UVB ( $p=0.0011$ using square root transformed data), but there were not more than 0.021 L. papula $\mathrm{ml}^{-1}$ in any treatment at the end of the experiment.

Despite the addition of glucose, bacteria in the absence of predation grew at approximately half the rate of picoautotrophs over the course of the experiment (Table 2). The natural grazer community, however, was capable of reducing the net bacterial growth rate to zero, accounting for $111 \%$ of the bacterial growth rate (Table 2). There was no significant difference in bacterial growth rate in the presence or absence of UVB ( $p=0.21$, Table 2). HNF grew only
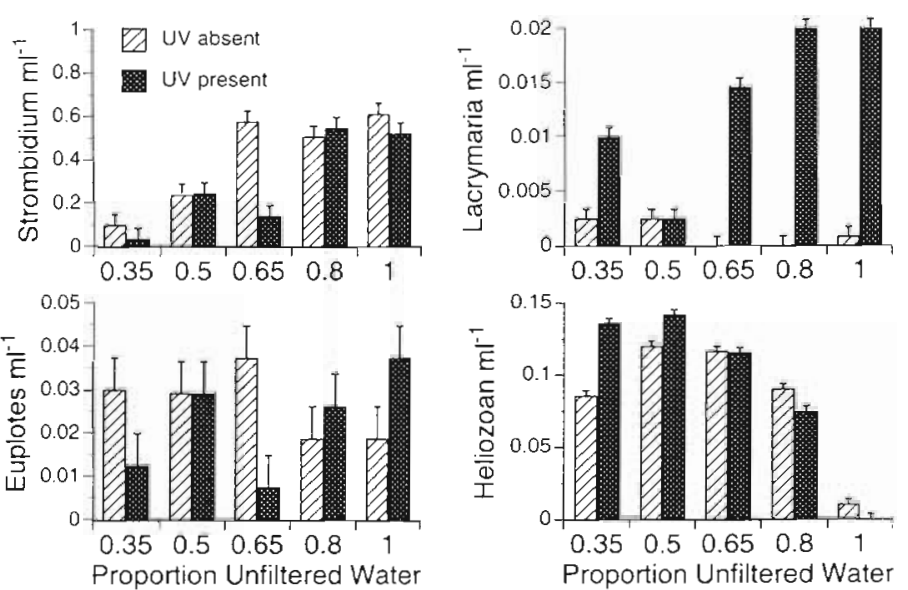

Fig. 3. Sea-ice meltwater pond dilution experiment. Final ciliate and heliozoan abundance in the presence and absence of UVB. Error bars are 1 least-squared standard error of the mean. Data were square-root transformed for statistical analysis, then back-transformed for the figures

slowly in the absence of predation $\left(0.069 \mathrm{~d}^{-1}\right.$, Table 2$)$. There was, however, no direct addition of food for heterotrophic flagellates, so it is unclear whether food was limiting for HNF, especially early in the experiment at high dilutions, where bacterial and algal abundances were low. Nevertheless, there was a good fit of the ANCOVA model to the data $\left(\mathrm{R}^{2}=0.58\right)$, with a strong grazing effect on HNF, although the relative size of the grazing effect may be an overestimate if the maximal HNF growth rate was underestimated. The UVB effect was marginally significant $(p=0.063)$, reducing by $47 \%$ the estimated maximal HNF growth rate. 

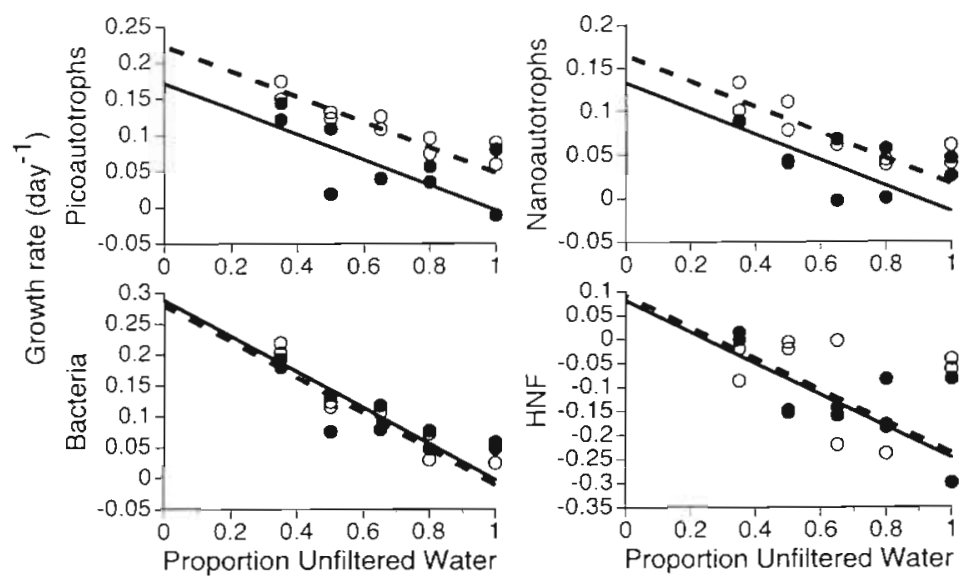

Fig. 4. Potsdam Lake dilution experiment. Regressions of proportion unfiltered water against net growth rate (per day) for pico- and nanoautotrophs, bacteria, and HNF. (-O-) UVB absent treatments, (- -) UVB present treatments. The slopes of the lines are the grazing rates, the intercepts are the growth rates in the absence of grazing. The $R^{2}$ values for the ANCOVA model fit and the estiraates of the slope (grazing rate) and intercept (growth in the absence of grazing) are given in Table 2

The second dilution experiment was conducted with water from Potsdam Lake, with greater UV absorption than the water from the ice meltwater pond, due to resuspended sediments (Fig. 1). Initial nutrients, chlorophyll, and bacteria levels were higher than in the meltwater pond dilution experiment (Table 1). Initial protist abundance was also somewhat higher than the first experiment (Table 1). There were a total of 9 ciliate species present, the most abundant being Halteria sp. and Urotricha sp. (57 and $15 \%$ of total initial ciliate abundance, respectively). There were also 4 rotifer species found, the most abundant being Polyarthra sp. (initial abundance 31.4 Polyarthra $1^{-1}$ ) and Lecane sp. (initial abundance 1.7 Lecane $\mathrm{l}^{-1}$ ).

Fitting a quadratic regression to the growth rate data indicated that the data were nonlinear. As a result, the $100 \%$ unfiltered water treatment data were excluded. This eliminated the nonlinear trend. In contrast to the meltwater pond dilution experiment, there were small, but significant, effects of UVB on both pico- and nanoautotrophs (Table 2, Fig. 4). The maximal picoautotroph growth rate of $0.223 \mathrm{~d}^{-1}$ was reduced by $23 \%$ by the presence of UVB ( $p=0.0013)$, while the nanoautotroph growth rate of $0.165 \mathrm{~d}^{-1}$ was reduced by $19 \%$ by UVB ( $p=0.014$, Table 2 , Fig. 4). The relative effect of grazers had a much greater impact on pico- and nanoautotrophs than did UVB. Grazing accounted for 78 and $90 \%$ of growth for pico- and nanoautotrophs, respectively ( $p<0.001$, Fig. 4 , Table 2 ). As in the meltwater pond dilution experiment, there was no interaction between grazing and UVB effects ( $p>0.1$, Table 2$)$.

Bacteria and HNF also showed strong grazing effects, but neither showed any effect due to UVB (grazing effects: $p<0.01$; UVB effects: $p>$ 0.5 ; Table 2). Similar to the meltwater pond experiment, grazing on bacteria could account for $100 \%$ of the growth rate in the absence of grazing, at least up to the $80 \%$ unfiltered water level. Here too, no food for HNF was directly added and, as a result, the estimates of growth in the absence of grazing and grazing as a percent of growth have to be treated with some caution.

Ciliate response to UVB removal was highly species specific. Two species, Askinasia sp. and Bursaridium sp., showed strong enhancement with the removal of UVB ( $p=0.002$ and $p=0.008$, respectively, Fig. 5). UVB had moderate negative effects on the most abundant ciliate, Halteria sp., and on Strombidium sp. $(\mathrm{p}=0.045$ and $\mathrm{p}=0.036)$, and a marginal effect on Balanion sp. ( $p=0.086$, Fig. 5). However, the second most abundant species, Urotrichasp., did not show a response to UVB removal ( $p=0.37$, Fig. 5). Final abundance of the mixotrophic flagellate Dinobryon sp. was also marginally greater when UVB were removed $(p=0.079)$. Species-specific responses by ciliates to the removal of UVB were also seen in an in situ experiment carried out in a Greenland land pond during the same period (Wickham \& Carstens unpubl. data).

Two rotifers, Polyarthra sp. and Lecane sp., were also present at the end of the experiment in sufficient numbers to analyze. The final abundance of both species was unaffected by the removal of UVB ( $p>0.25)$, but with Lecane sp., there was an interaction between the dilution fraction and the UVB effect, with a significant suppression due to UVB occurring in the undiluted samples ( $p=0.014$, Fig. 5). In addition, the ratio of eggs per Polyarthra sp. was unchanged by the presence or absence of UVB ( $p=0.73)$, suggesting that in a longer-term experiment, UVB effects would be unlikely to emerge. Differences in UVB susceptibility between different metazooplankton species have previously been found (Siebeck 1978, Williamson et al. 1994). Ours is the first study to show negative effects of UVB on ciliates, but here too, suppression was not uniform, with large species-specific differences. These results suggest that there are few generalities that can be made about either metazooplankton or protist vulnerability to increasing UVB loads.

\section{DISCUSSION}

There has been a considerable amount of work on the negative effects of UVB on algae and bacteria (Holm-Hansen et al. 1989, Cullen et al. 1992, Müller- 
Niklas et al. 1995, Jeffrey et al. 1996), but we could find community-level effects on pico- or nanoautotrophs in only the Potsdam Lake experiment, and no negative effects of UVB on bacteria in either experiment. Potsdam Lake was highly turbid with less UVB penetration than the meltwater pond (Fig. 1). A similar pattern was also seen in 2 in situ experiments, also run in turbid and clear-water environments in Greenland during the same period as these experiments (Wickham \& Carstens unpubl. data). These results suggest that in the clear-water environments, algae were adapted to high light conditions, including UVB. Tropical phytoplankton, which are exposed to high UVB loads, have been shown to be more resistant to UVB than Antarctic phytoplankton, and cyanobacteria grown in the presence of UV had higher amounts of UV-protective compounds than cells grown in the absence of UV (Helbling et al. 1992, Garcia-Pichel \& Castenholz 1993). A similar phenomenon would explain the differences in vulnerability to UVB in algae from clear and turbid habitats.

Bacteria were the group least vulnerable to UVB. In neither experiment could we find any differences in growth rate or final abundance due to UVB. A similar pattern was also seen in 2 in situ experiments (Wickham \& Carstens unpubl. data). Previous work has shown that UVB can damage bacteria in the field (Herndl et al. 1993, Jeffrey et al. 1996), making our results unexpected. However, in an in situ study conducted in a freshwater subarctic lake, bacteria did not respond to the removal of UVB, at least in the absence of additional phosphorus (Bergeron \& Vincent 1997). This suggests that bacterial vulnerability to UVB cannot be assumed. Photolysis of recalcitrant DOM to more utilizable forms can result in higher bacterial abundance (Lindell et al. 1995), which would counter the direct, negative effect of UVB on bacteria. However, initial DOC in our experiments was beneath $2 \mathrm{mg} \mathrm{l}^{-1}$, and in the Bergeron and Vincent (1997) study, under $3 \mathrm{mg} \mathrm{l}^{-1}$, so it would seem unlikely that there was photolysis of DOM countering the direct inhibition of bacteria. It is also unlikely that the lack of an observable effect was due to high variance in our data. In the Potsdam Lake dilution experiment, the fit of the data to the ANCOVA model was good $\left(\mathrm{R}^{2}=\right.$ 0.81 ), but the difference in bacterial growth rate in treatments with, and without, UVB was extremely small. Length of exposure to UVB also plays a role in determining the degree of vulnerability to UVB damage. When exposed to natural UVB for a $4 \mathrm{~h}$ period, bacteria have been shown to be able to recover to
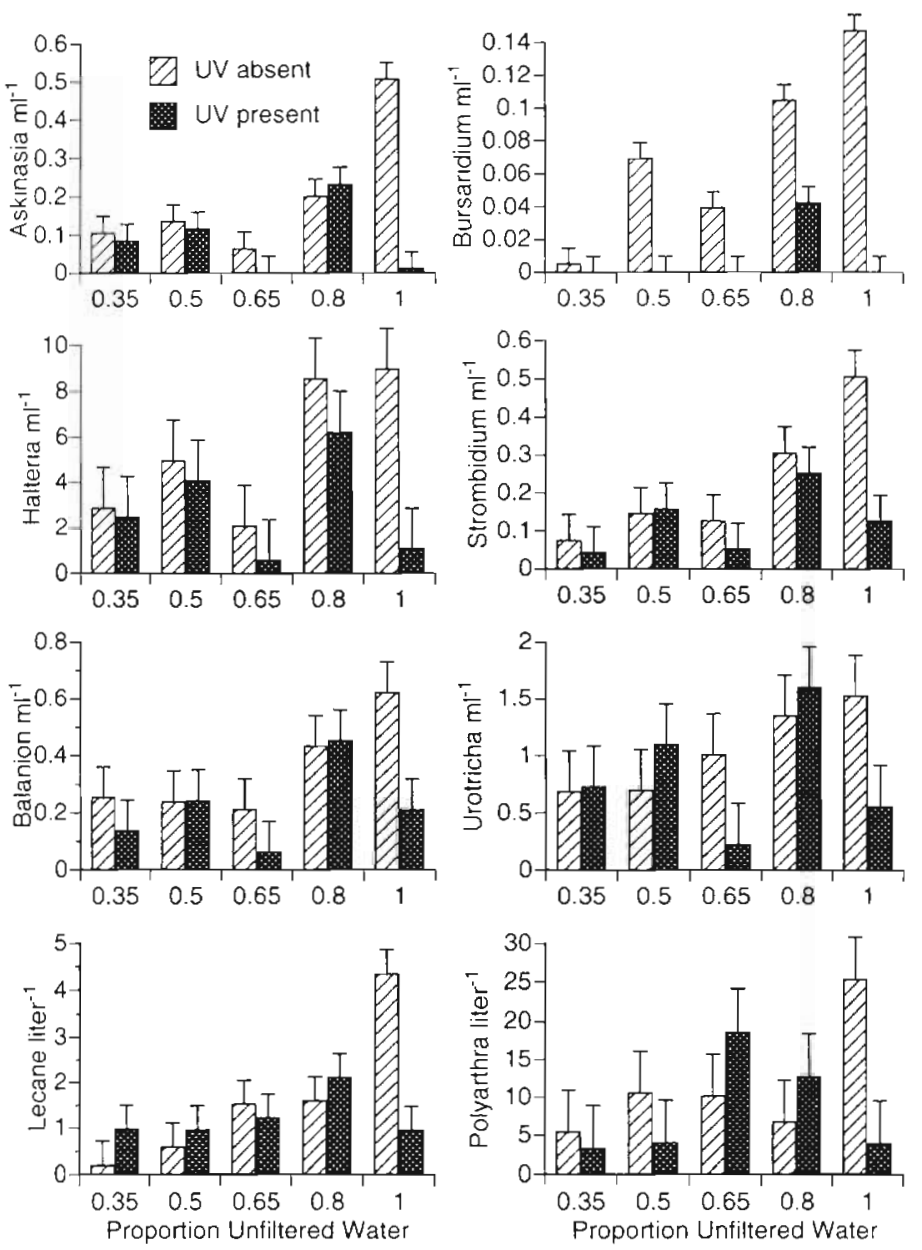

Fig. 5. Potsdam Lake dilution experiment. Final ciliate and rotifer abundance in the presence and absence of UVB. Error bars are 1 least-squared standard error of the mean. Rotifer data were squareroot transformed for statistical analysis, then back-transformed for the figures

abundances comparable to bacteria in the dark (Müller-Niklas et al. 1995). While day length at the time of our experiments was approximately $15 \mathrm{~h}$, the sun was relatively low in the sky (not more than $30^{\circ}$ above the horizon), thus making the time of exposure to UVB somewhat uncertain. It is possible that bacteria did not get a sufficiently large UVB dose for a long enough period to produce measurable suppression. Jeffrey et al. (1996) concluded that bacteria suffered more DNA damage due to UV exposure than eukaryotic microorganisms, but our data suggest that bacteria may at times be less vulnerable to UVB damage than are eukaryotes.

We found significant suppression of HNF in only the meltwater pond dilution experiment (Table 2). Deleterious effects of UVB have also been shown for HNF, but using a single flagellate species (Sommaruga et al. 1996). We counted HNF using epifluorescent micro- 
scopy, which does not allow for taxonomic differentiation. Species-specific differences in UVB vulnerability are known for algae and metazooplankton (Siebeck 1978, Karentz et al. 1991. Williamson et al. 1994, Davidson et al. 1996) and our work showed speciesspecific differences for ciliates. We cannot rule out the possibility that there were also differences in HNF vulnerability to UVB that were masked by our counting methodology, and that with better HNF taxonomic resolution, species-specific differences would have been apparent.

In the ANCOVA analysis, none of the grazing rates (the slopes of the regressions) were significantly altered by removing UVB (interaction effect, Table 2). Thus, community grazing rates were not altered by removing UVB. This is in contrast with the results found by Bothwell et al. (1994), where the algal biomass in artificial streams increased when UVB was present, due to the suppression of a chironomid grazer. However, not only was that a very different environment from those examined in our study, but in the Bothwell et al. (1994) work, all the grazers were chironomids, the majority coming from a single species. In the Potsdam Lake experiment, there were 2 rotifer species and 8 ciliate species that could be considered algal grazers. While they are of varying susceptibility to UVB, the net effect was not to alter the community grazing rates.

The experiments also indicated that when UVB effects were found, their effect on growth rates was substantially less than that imposed by grazing. In the Potsdam Lake experiment, where there was an UVB effect on phytoplankton growth, the depression in pico- and nanoplankton growth rates was 23 and 19\%, respectively, of the growth rates in the absence of predation (Table 2). In contrast, the community grazing impact was 78 and $90 \%$ of the growth in the absence of predation. Similarly, when there was an effect on HNF growth rate in the meltwater pond experiment, the depression in growth due to the presence of UVB was $47 \%$ of the growth in the absence of predation, while the grazing effect was over twice as large as the growth rate in the absence of predation (Table 2). Both the HNF estimates are most likely too large, given that there was only an indirect addition of food for HNF, by providing nutrients for bacteria and phytoplankton. Even if HNF growth was underestimated, however, the impact of grazing on HNF growth relative to the impact of UVB on HNF growth should remain the same, with grazing several times more important than UVB in regulating HNF growth.

These experiments indicate that, as yet, general UVB effects cannot be easily ascertained for entire arctic microbial food webs. Effects were at times quite strong, but for the heterotrophs at least they were species spe- cific. Even for autotrophs, we could find significant UVB effects in only 1 experiment, and they were overshadowed by the size of grazing effects. In the communities we studied, the removal of UVB had no net effect on bacteria, consistent with results of another community-level study (Bergeron \& Vincent 1997), but in contrast to deleterious effects of UVB documented in other studies. However, the continuing depletion of stratospheric ozone is expected to raise ground-level UVB load disproportionately at high latitudes, increasing the UV loads likely to produce plant and DNA damage at 70 to $75^{\circ} \mathrm{N}$ (the region in which we worked) by 9 to $10 \%$ per decade (Madronich 1992). Thus with future, higher UVB loads, there may be less scope for UVB resistance, and therefore more widespread negative effects of UVB on microbial food webs.

Acknowledgements. We thank Captain E. Greve and the crew of the RV 'Polarstern' for the cooperation and help they provided during the 'Polarstern' cruise ARKTIS-X/2, and the cruise leader, H.W. Hubberten, for the considerable helicopter time and lab space he made available. We also thank D. Lemke for the chlorophyll and UV absorbance measurements, D. Albrecht for the nutrient analysis, and H. Rai for an introduction to the UV literature. M. Spindler is thanked for supporting our participation in the cruise. The manuscript was improved through discussions with F. Garcia-Pichel and U.-G. Berninger, and through the comments of 3 anonymous reviewers. The experiments were conducted while S.W. was a post-doctoral fellow at the Max Planck Institute for Limnology, and the financial support of the Max Planck Society is gratefully acknowledged. Similarly, M.C. gratefully acknowledges financial support by the German Research Council (Deutsche Forschungsgemeinschaft) through grant $\mathrm{Sp} 377$ 2/2 to M. Spindler.

\section{LITERATURE CITED}

Bergeron M, Vincent WF (1997) Microbial food web responses to phosphorus supply and solar UV radiation in a subarctic lake. Aquat Microb Ecol 12:239-249

Bothwell ML. Sherbot DMJ, Pollock CM (1994) Ecosystem response to solar ultraviolet-B radiation: influence of trophic-level interactions. Nature 265:97-100

Cullen JJ, Neale PJ, Lesser MP (1992) Biological weighting function for the inhibition of phytoplankton photosynthesis by ultraviolet radiation. Science 258:646-649

Davidson AT, Marchant HJ, de la Mare WK (1996) Natural UVB exposure changes the species composition of Antarctic phytoplankton in mixed culture. Aquat Microb Ecol 10: 299-305

Gallegos CL (1989) Microzooplankton grazing on phytoplankton in the Rhode River, Maryland: nonlinear feeding kinetics. Mar Ecol Prog Ser 57:23-33

Garcia-Pichel F, Castenholz RW (1993) Occurrence of UV absorbing, mycosporine-like compounds among cyanobacterial isolates and an estimate of their screening capacity. Appl Environ Microbiol 59:163-169

Helbling EW, Villafañe V, Ferraria M, Holm-Hansen O (1992) Impact of natural ultraviolet radiation on rates of photosynthesis and on specific marine phytoplankton species. Mar Ecol Prog Ser 80:89-100 
Herndl GJ, Müller-Niklas G, Frick J (1993) Major role of ultraviolet-B in controlling bacterioplankton growth in the surface layer of the ocean. Nature 361:717-719

Holm-Hansen O, Helbling EW (1993) Polyethylene bags and solar ultraviolet radiation. Science 259:534

Holm-Hansen O, Mitchell BG, Vernet M (1989) Ultraviolet radiation in antarctic waters: effect on rates of primary production. Antarct J US 24:177-178

Jeffrey WH, Pledger RJ, Aas P, Hager $S$, Coffin RB, Von Haven R, Mitchell DL (1996) Diel and depth profiles of DNA photodamage in bacterioplankton exposed to ambient solar ultraviolet radiation. Mar Ecol Prog Ser 137: 283-291

Karentz D, McEuen FS, Land MC, Dunlap WC (1991) Survey of mycosporine-like amino acid compounds in Antarctic marine organisms: potential protection from ultraviolet exposure. Mar Biol 108:157-166

Landry MR, Hassett RP (1982) Estimating the grazing impact of marine micro-zooplankton. Mar Biol 67:283-288

Lindell $M, E d l i n g ~ H(1996)$ Influence of light on bacterioplankton in a tropical lake. Hydrobiologia 323:67-73

Lindell MJ, Granéli W, Tranvik LJ (1995) Enhanced bacterial growth in response to photochemical transformation of dissolved organic matter. Limnol Oceanogr 40: 195-199

Madronich S (1992) Implications of recent total atmospheric ozone measurements for biologically active ultraviolet radiation reaching the earth's surface. Geophys Res Lett 19:37-40

Melles M, Akimov AM, Diepenbroek M, Goerke O, Grobe H, Müller G, Niessen F (1995) Lacustrine sedimentology. In: Hubberton HW (ed) Reports of polar research 174: the expedition ARKTIS-X/2 of RV 'Polarstern' in 1994. AlfredWegener-Institut für Polar- und Meeresforschung, Bremerhaven, p 52-62

Editorial responsibility: John Dolan,

Villefrance-sur-Mer, France
Montagnes DJS, Lynn DH (1987) A quantitative protargol stain (qps) for ciliates: method description and test of its quantitative nature. Mar Microb Food Webs 2:83-93

Müller-Niklas G, Heissenberger A, Puškarić S, Herndl G (1995) Ultraviolet- $B$ radiation and bacterial metabolism in coastal waters. Aquat Microb Ecol 9:111-116

Nusch EA, Palme G (1975) Biologische Methoden für die Praxis der Gewässeruntersuchung. Wasser/Abwasser 116:562-565

Prézelin BB, Smith RC (1993) Reply to Holm-Hansen and Helbling. Science 259:534-535

Siebeck O (1978) Ultraviolet tolerance of planktonic crustaceans. Verh Int Ver Limnol 20:2469-2473

Skibbe O (1994) An improved quantitative protargol stain for ciliates and other planktonic protists. Arch Hydrobiol 130 339-347

Sokal RR, Rohlf FJ (1995) Biometry. WH Freeman and Company, New York

Sommagura R, Oberleiter A, Psenner R (1996) Effect of UV radiation on the bacterivory of a heterotrophic nanoflagellate. Appl Environ Microbiol 62:4395-4400

Vinebrooke RD, Leavitt PR (1996) Effects of ultraviolet radiation on periphyton in an alpine lake. Limnol Oceanogr 41 : $1035-1040$

Williamson CE, Zagarese $\mathrm{HE}$, Schulze PC, Hargreaves BR, Seva J (1994) The impact of short-term exposure to UV-B radiation on zooplankton communities in north temperate lakes. J Plankton Res 16:205-218

Williamson CE, Stemberger RS, Morris DP, Frost TM, Paulsen SG (1996) Attenuation estimates from DOC measurements and implications for plankton communities. Limnol Oceanogr 41:1024-1034

Winer J (1971) Statistical principles in experimental design McGraw Hill, New York

Zellmer ID (1995) UV-B-tolerance of alpine and arctic Daphnia. Hydrobiologia 307:153-159

Submitted: September 2, 1997; Accepted: July 7, 1998

Proofs received from author(s): November 9, 1998 